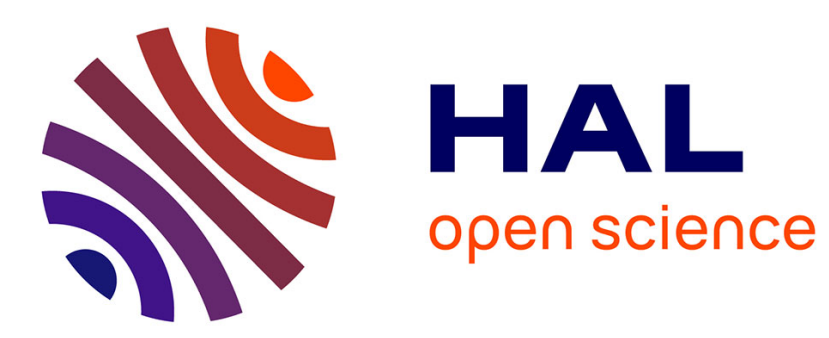

\title{
cultural geographies in practice
}

Heidi J. Nast

\section{To cite this version:}

Heidi J. Nast. cultural geographies in practice. cultural geographies, 2005, 12 (1), pp.89-101. 10.1191/1474474005eu319xx . hal-00572143

\section{HAL Id: hal-00572143 \\ https://hal.science/hal-00572143}

Submitted on 1 Mar 2011

HAL is a multi-disciplinary open access archive for the deposit and dissemination of scientific research documents, whether they are published or not. The documents may come from teaching and research institutions in France or abroad, or from public or private research centers.
L'archive ouverte pluridisciplinaire HAL, est destinée au dépôt et à la diffusion de documents scientifiques de niveau recherche, publiés ou non, émanant des établissements d'enseignement et de recherche français ou étrangers, des laboratoires publics ou privés. 


\section{cultural geographies in practice}

\section{Representing possibilities: the DuSable Museum meets the Kano palace}

\section{Heidi J. Nast}

Department of International Studies, Depaul University, Chicago

In the fall of 2002 I was awarded a one-year Fellowship at DePaul University's new 1 Humanities Center. One of the conditions for accepting the award was that each Fellow develop a 'community outreach' project to communicate some facet of the work accomplished during their tenure. My project involved preparing for production my book on the Kano palace of northern Nigeria. ${ }^{1}$ Concubines and power: five hundred years in a northern Nigerian palace (2004). The palace, built c. 1500, is the largest extant palace in West Africa and was organized along Islamic principles, especially the seclusion of royal wives and concubines in a large interior area known as the ciki. The palace was purposefully kept intact during the colonial period (1903-60), allowing it to be used for purposes of indirect rule over the emirate, Kano having been the most economically successful of all of the emirates that in the nineteenth century made up a large regional caliphate. Today, over 1000 persons reside there, including the emir of Kano, royal women and children, and persons of palace slave descent. Palace slavery was historically a high-status institution, the British forcibly 'freeing' and exiling palace slaves in a special 1926 edict because they were too powerful and were using their powers to resist British rule.

Given my historical interests in the palace, I resisted the stipulation for community outreach, assuming few persons other than academics would be interested in West African royal concubines. Whilst discussing potential projects during a Fellows' meetings at the Center, the Director suggested in passing to me that I do something more simple than what I was proposing - working at length with a school partly serving the Cabrini Green community (Cabrini Green is the site of one of the most notoriously 
neglected Chicago housing projects). Why not, she suggested, show some photographs of the palace in some public context or other and talk about the work that way?

The idea took hold, especially since I had hundreds of photographs from 1988-90 and 2000 that had never been adequately considered in my published works. As part of the Fellowship, I had enrolled in a graphic design course that allowed me the skills needed to complete the graphics for my forthcoming book, my Program Chair allotting me the monies to purchase high-resolution scanning equipment, along with the appropriate software. Community outreach now seemed easy.

In late fall of 2002, I began sorting through my photographs, realizing in the process two representational dilemmas. First, the story of the palace is structured, for me, around the lives of royal concubines and wives. And yet I knew that exposing photographs of the adult women of the family of the emir (the traditional ruler) would be culturally inappropriate and deeply offensive. How, then, was I to represent the lives and agency of royal wives and concubines, the majority of whom I would make sure the audience would never see? Secondly, many persons serving the emir proudly identify themselves as bayin sarki, 'slaves of the king'. How was I to describe persons scarified as royal bayi (three scars etched whisker-like on either side of the mouth three days after birth) to persons in a place (Chicago) renown as the most segregated city in the US? How I negotiated these two representational dilemmas is the stuff of this essay.

\section{Choosing a place}

With a small grant provided to me by the Humanities Center, I had about a dozen of my slides made into photographs and mounted for gallery showing. These I hoped to cart around to various Chicago sites in an effort to sell the idea of a photographic exhibition. In December 2002 I set off first to the DuSable Museum of African American History.

I chose the DuSable because it is the largest and most renowned independent museum in the US dedicated to preserving and interpreting the history and achievements of African Americans. Unlike the Field Museum's outstanding exhibition on Africa, moreover, the DuSable museum's exhibitions were to my mind not tainted by institutional associations with nineteenth-century 'white' colonialism. Rather, the DuSable was created out of African American desires to found an institution beholden to the black community and honouring the first permanent settler in Chicago, the Haitian fur trader Jean Baptist Pointe DuSable. ${ }^{2}$ Whereas most Chicago museums are located in (or north of) the downtown area and serve a largely white audience, the DuSable Museum is located in Chicago's south side and is renown for its outreach to the surrounding African American community. Its history and political sensibilities made it an ideal place from which to launch an exhibit about a monumental and beautiful place that had emerged out of the complex Islamicized urban political culture of a formidable African city-state (Kano) in the late $1400 \mathrm{~s}$. The Kano palace had historically been built and managed by slaves, the utility and quality of the most elite palace slaves' lives being much removed from those of the New World.

As fortune would have it, the DuSable curator, Dr Selean Holmes, had lived for some time in Sokoto, northern Nigeria, the former capital city of a pre-colonial regional 
caliphate. She had for some time wanted an exhibit that would foreground the Islamic context of northern Nigeria-most persons associating Nigeria with the vibrant non-Muslim cultures of southern Nigeria, especially the Yoruba. Soon after viewing the photographs, Dr Holmes accepted the proposal for the exhibit and we began the somewhat lengthy process of getting the exhibit passed by the DuSable board (which was accomplished successfully) and thereafter organizing and carrying out the logistics of launching a city-wide exhibit.

\section{Naming the exhibit}

I decided to name the exhibit 'Disrupting perceptions' to foreground the fact that the exhibit would be set up to challenge four popular misconceptions in the US about Africa and African cultures, my objectives in turn effecting the representational dilemmas alluded to, above. The first misconception is that pre-colonial sub-Saharan Africa has always been utterly rural and has had no large urban centres or complex state structures. I hoped to challenge this perception by having the photographs point to the palace's complex political culture and by foregrounding the palace's embeddedness in a process of Islamization and urbanization that began in the 1400s as a result of scholarly in-migration from across the Sahara. Secondly, I wanted to challenge the perception that all slavery in the world was like the chattel slavery that existed in the Americas, an inherited condition characterized by a complete absence of social authority and based on racism. By contrast, I hoped the exhibit would emphasize that thousands of slaves served the Kano palace in a number of capacities and that many palace slaves were enormously powerful and wealthy, not unlike those in ancient Rome. Powerful male slaves administered state lands, were military advisers, leaders, and soldiers; maintained a palace-based cavalry; ran palace blacksmithing facilities (eventually manufacturing guns); and served as important political advisers and leaders for the king. The most powerful female slaves were concubines, a form of slave taken by a wealthy owner to bear his children. Slavery was not based on racism or preconceived ideas about skin colour.

The exhibit would also challenge the notion that concubines were debased slaves with no rights whose sole purpose was to satisfy male sexual desire. This would be done by showing, through photographs and maps, that the largest area in the Kano palace was (more than $80 \%$ of the $540 \mathrm{~m} \times 260 \mathrm{~m}$ structure) reserved for royal women in Islamic seclusion, along with their children and servants. Within this area, referred to as the ciki (inside) in the local language of Hausa, hundreds of women had historically lived, most of them royal concubines who had been prisoners of war. Within the historical regional context of enslavement, royal seclusion inside a magnificent palace was a sign of privilege and prestige: here, these women would be accorded royal prerogatives, would hold considerable power and rank, and would have many slave women serving under them. They were also guaranteed kingly patronage for life. In return, they administered life in the massive palace core. Some served as political representatives of the territories from which they were captured; others helped administer 
grain tax collection; while still others fed about 2000 persons daily. Islamic law, moreover, stipulated that concubines who had borne children were to be freed upon their master's death. In this sense, concubinage promised freedom.

Lastly, the exhibit would challenge the perception that all concubine children were chattels that could be sold into slavery. This was indeed the case under slavery in the Americas, where a child born of a slave woman inherited its mother's status. In Kano, in keeping with Islamic law, a concubine's child has the same birthrights as the freeborn father, regardless of who their mothers were. Palace concubine children were thus princes and princesses, just as were the children of freeborn wives. Many Kano kings have been sons of concubines, including the current ruler. Even today, the birth of a concubine child is recognized and celebrated by the entire palace community.

These misperceptions would be addressed not only by the photographs but by maps posted above each set of photographs, and by a twelve-page catalogue where more information about each photograph could be obtained. A one-page flyer provided a résumé of this information, along with maps of Africa and Nigeria and aerial photographs of Kano city (in the 1500s it was one of Africa's three most important cities), and the palace.

\section{Representing without 'seeing'}

To disrupt such perceptions, I first had to figure out how to foreground the importance of royal concubines without showing their images outright. Most royal women (including concubines) would abhor being seen in public, besides the fact that any husband would be much insulted if the women of his inner secluded household were placed on view without his consent. Throughout my fieldwork (1988-90, 2000, 2003), it was made clear to me that proper royal women would never deign to have their photographs taken for strangers to see them. I therefore rarely photographed palace concubines or wives; if I did so, I sent the photographs to those photographed, for their own personal pleasure, to be circulated amongst their immediate family and friends.

I negotiated my first dilemma, then, by choosing photographs and crafting catalogue captions that highlighted the grandeur of where concubines lived or by foregrounding the material-objective fruits of their at times extraordinary histories and labours. Take, for example, Photograph 8, titled 'Abundance' (Yelwa) (Figure 1), which featured an annotated reproduction of a 1903 sepia photograph taken by the British just after their conquest of the palace. Abandoned, the place appears eerily silent and strikingly majestic. As we look out eastward from a large palace field in the foreground, we see that the interior landscape includes two extremely long, monumental adobe structures running parallel to one another, the one in the background featuring a second floor and a domed armoury, both structures featuring meshed, rectangular windows. The area in the mid-ground features the most important concubine 'ward' known as Yelwa or 'Abundance' where all of the most important title-holding concubines lived and where the massive central kitchen was located. As the catalogue caption points out, it was here that food for thousands of persons was produced through a complex hierarchy of concubines and slave women. Arrows point out to the viewer the name and/or function of 


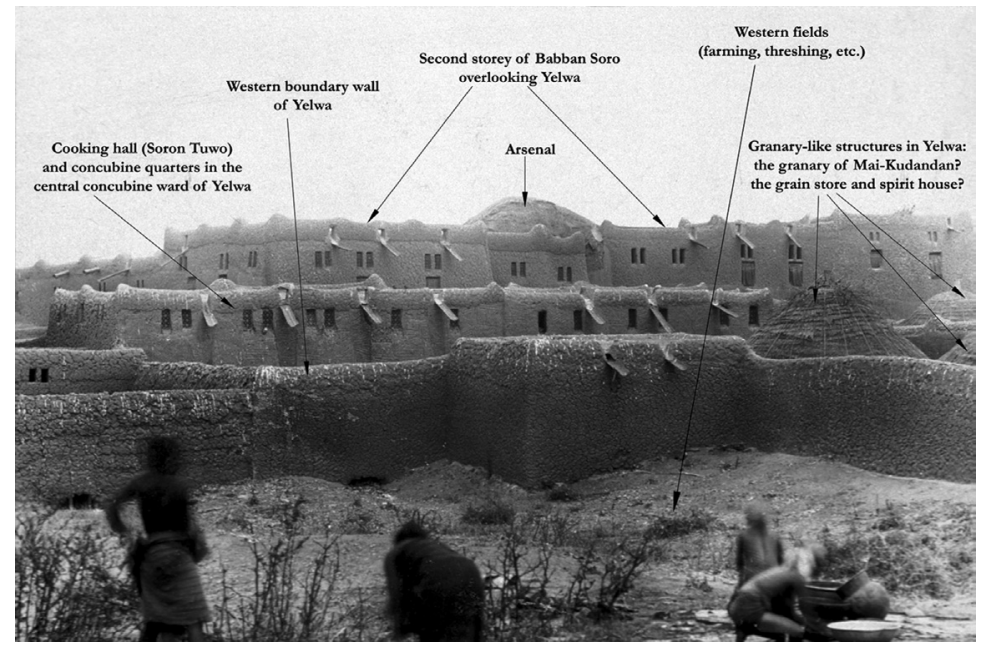

FIGURE 1 Photograph 8, 'Abundance' (Yelwa). The largest and most important concubine-slave 'ward' in the palaces's secluded female interior, 1903. Herein lay the central palace kitchen and the residences of the highest-ranking title-bearing concubines and slave women. Food production was a monumental affair, concubines administering to the cooking of grains for about 1 500-2 000 persons daily. Yelwa's central cooking hall stands in the middleground and was located in the exact centre of the secluded ciki or 'inside'. Yelwa was also where palace women carried out spirit practices, known as bori. After the British conquest of Kano city-state, British officials passed through the palace taking photographs of its largely abandoned landscape. The long, massive building in the background is the king's chamber, which included a domed armoury.

each structure, information gleaned in discussions with elderly palace women. The photograph and caption thus relayed important information - the ward-based organization of palace concubines, the importance of toponyms in marking place function, the huge scale of the concubine-controlled food production process, and the monumentality and beauty of the palace structures - without exposing the women themselves. Moreover, the photograph's annotations reflected the fruits of discussions with female elders, many of whom were delighted by a photograph that helped them remember place names and a landscape only they had experienced and known.

'Bride in blue' (Photograph 10, Figure 2) was similarly instructive about concubine life without putting them in the picture. The photograph features a close-up of the king's (emir's) young daughter, Sadiya Ado Bayero, who looks solemnly off in the distance. She wears a powder-blue dress and a dark blue headscarf; her neck and ears are demurely adorned with bright gold and coral jewellery. In the background, out of focus, stand other palace women visiting the palace for the event at hand: the marriage celebrations for six royal brides. Palace brides are married communally once a year because the emir has so many children (almost 100). Her photograph is part of a series of six, three of which feature palace women of slave descent actively involved in various labours needed to produce the massive wedding feast. 


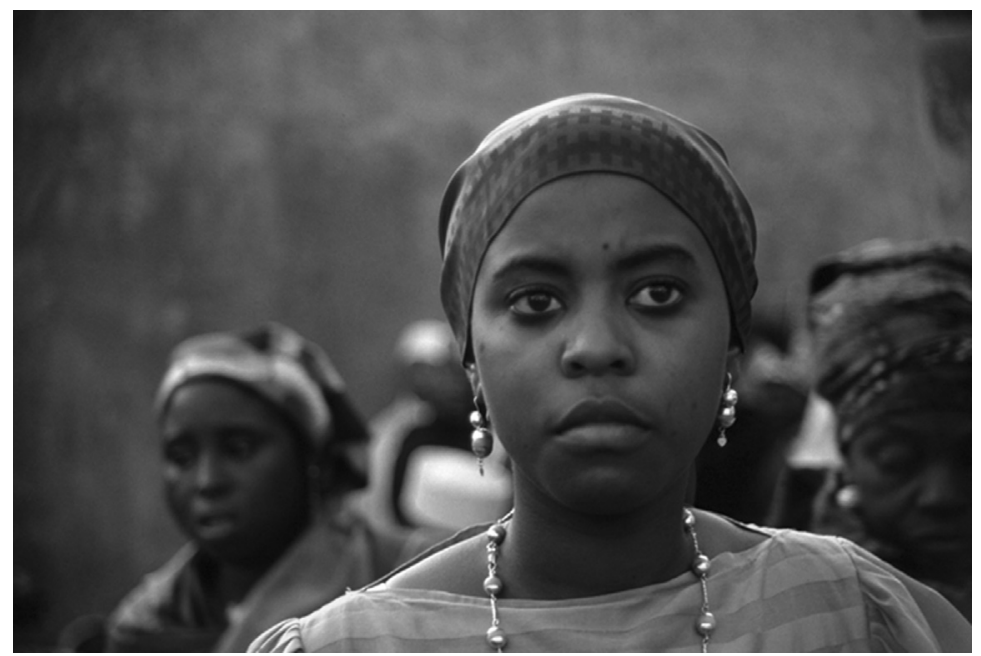

FIGURE 2 Photograph 10, 'Bride in blue'. Royal brides must wear blue on their wedding day, a tradition that probably dates back hundred of years, though young women today do not understand why they must do so. Throughout much of West Africa, blue was associated historically with the queen mother, royal women generally, and/or female fertility. In Kano, hundreds of palace concubines dyed homespun cotton cloth with indigo blue dye. Eventually, indigo-dyed cloth became valuable in long-distance trade and in some cases was used as currency. In the late 1700s, the size of the vessels used in the palace dyeing yard increased. After the 1807 religious war, the Fulani king shut down the dyeing yard and instead transferred the industry to male Islamic scholars and students, the industry soon being taken up by other men to become one of the city-state's economic mainstays. At the same time new laws were created forbidding women from the industry.

Like most of the photographs, 'Bride in blue' was used to speak to the many social and political processes of which much of her social person is an effect: the colour blue, for example, is the colour that concubines require all brides to wear, though the young brides and many concubines no longer know why. My research shows, however, that blue was historically a colour related to fertility, femaleness, and royalty - something common throughout West Africa; and that palace concubines may have monopolized indigo-dyeing since the sixteenth century, later innovations in indigo-dyeing pot technology tied partly to the technology of massive cooking pots. Concubines administered the cloth-dyeing in a huge dyeing yard abutting Yelwa. The caption for the photograph relays this information, in addition to the fact that after the dyed cloth became a particularly lucrative venture in the early nineteenth century the dyeing industry was wrested away from women and placed firmly in the hands of men (I conjecture that by the seventeenth century, indigo dyeing had escaped the palace confines and become the domain of rural and urban women, generally). Special laws were even passed forbidding Kano women to participate in the industry, which by the nineteenth century was one of the economic mainstays of the city. 
What I should and could have noted in the catalogue caption (only now have I thought of it) is that Sadiya, a royal princess, is the great-granddaughter of a concubine captured in Niger and brought to the palace of Katsina (historically, a rival city-state to the northwest). Before going ahead with gallery production of this photograph, I called Sadiya's husband for permission (he is a member of the royal family and a banker based in Lagos), which he gave me. I then asked him to request permission from Sadiya as well; she lives in Kano, and at the time had no working phone. ${ }^{3}$ In this way, I followed cultural protocol.

The third photograph used to evince a concubine presence and concubine histories and labours was Photograph 17, 'Talia' (Figure 3). Here we see a concubine named Asmau bent over at the waist, her head pointed towards us, her face thus obscured. Her right hand reaches out and turns the crank on a shiny new manual spaghetti maker, out of which stream noodles. In front of her left leg is a small stool upon which sits a sheet of rolled-out spaghetti dough, ready to be made into spaghetti after she finishes with the first sheet. Off to her right on the ground is a straw mat upon which are reams of spaghetti strands drying in the sun, waiting to be collected up and sold. The catalogue caption tells the viewer that talia is the Hausa word for spaghetti, a noodle probably introduced into Kano centuries ago as a result of trans-Saharan Mediterranean trade where goods from Italy (hence, talia) could be obtained. A primary source from

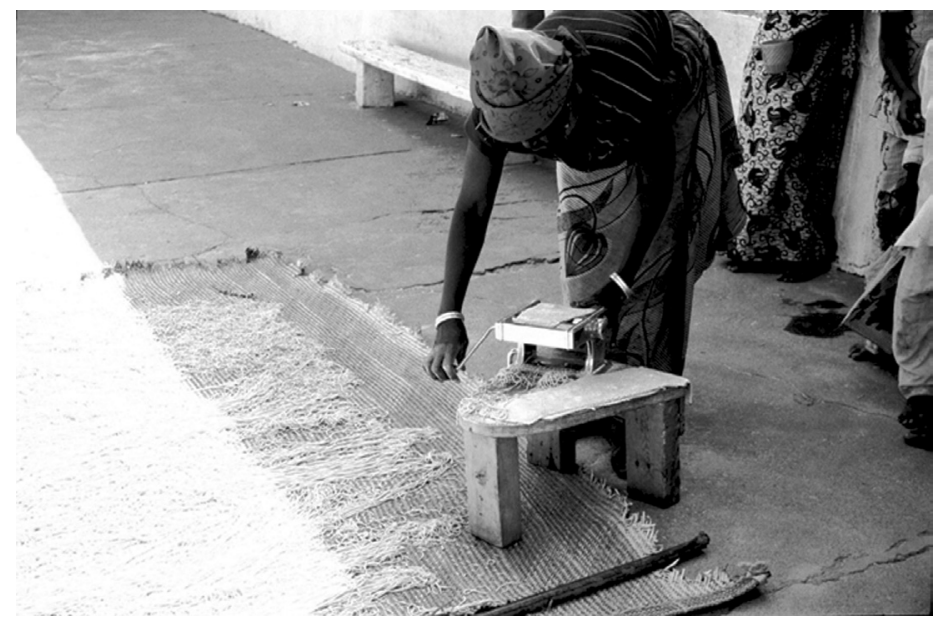

FIGURE 3 Photograph 17, 'Talia'. A palace concubine makes talia or spaghetti using a modern device. Talia has been known in Kano for probably hundreds of years. The word derives from Italy or 'Italia'. Wheat is a delicacy consumed mostly by aristocracy. In the 1500 s Kano was one of the three most important cities of Africa and a renowned entrepôt intersected by several major trans-Saharan trade routes. Trans-Saharan traders stayed in North and West African towns for months or years at a time, establishing families and kinship networks. Likewise, North and West African Islamic merchants and scholars travelled southward, establishing themselves in villages and towns, including Kano. Talia's presence in Kano shows how vital precolonial KanoMediterranean connections were, connections the British severed after their conquest of 1903. 
the mid-1800s tells us that wheat, the primary ingredient, was a crop grown for, and consumed mostly by, royalty. Concubines must therefore have learned how to reproduce the noodle using locally grown wheat, the concubine in the photograph showing how technological innovations continue to be employed. The photograph hence focuses on the phenomenon of noodle production, rather than on the body or face of the concubine per se, showing how concubines were enmeshed in innovations tied to trans-Saharan trade and, today, in the consumption of new foodproduction technologies. The photograph and caption also explain that Yaya Asmau's labours are part of a commercial venture, with initial capital outlay provided by one of the wives. In this way, the reader is also made aware that although royal women are secluded, they can be independent businesswomen, and that royal wives and concubines live co-operatively within the same palace interior.

\section{Representing 'difference' in slavery}

The second major concern I had, one of special import to the Museum curator, was how to depict palace slavery. The problematic nature of depicting the institution first became clear to me whilst describing the project early on to an African American friend and graphic designer whose input I was soliciting. She became visibly upset as I described the exhibit and declared that as an African American she found my description offensive: how could I use the term 'elite' to describe any slavery context? As she pointed out, most African Americans would find an exhibit celebrating any slave-based culture to be insulting. Our ensuing discussions, wherein I attempted to explain the differences between US and northern Nigerian slavery, were fruitful, helping me to figure out the contours of how the exhibit might be framed. The argumentational contours of this framing became even clearer after I met with the Director of Education for the Museum, Dr Stephanie Davenport. Dr Davenport also emphasized the representational dilemma; the last thing desired was for a largely African American viewing audience (estimated at 5000 persons over the three-month period) to think a white woman was relaying how marvellous and productive slavery could be. In most US minds, the only form of slavery recognized or known was that of the Americas. There had to be a clear platform for registering differences amongst slavery systems. We therefore carefully reviewed all of my photographs together and Dr Davenport chose one that she thought could be used for public pedagogical purposes: Photograph 22, 'King of Grain' (Figure 4). The image features a man dressed in brilliantly coloured striped robes and a heavily embroidered brocade cape. On his head sits a large turban made partly with gold-coloured threads. His hand holds his cup of office, an Islamic standard for measuring grains, the surface of which bears an Arabic inscription praising Allah. He stands under an adobe archway in a regal posture, staring into the camera, the sunlight falling in a way that make the golden threads in the cloth of his turban glisten and the colors of his robes especially vibrant. Here is Sarkin Hatsi (King of Grain), historically a slave titleholder of modest status, his roots in slavery evident in the $u k u$-uku, the three characteristic scarification marks etched along either side of a slave child's mouth only 


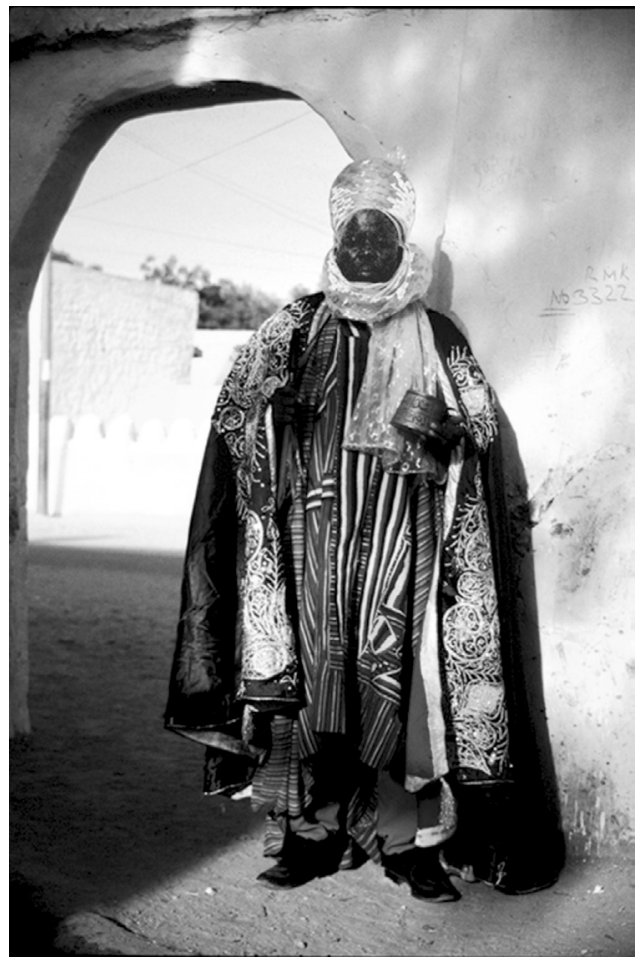

FIGURE 4 Photograph 22, 'King of Grain'. King of Grain wears the traditional robes of state and holds his cup of office, a cup designed to serve as the standard Islamic grain measure, the mudu. King of Grain was a state title invented in the mid-1800s and held by a eunuch. This photograph shows the office holder today, a proud descendant of powerful slaves who ran the state, known as bayin sarki, or 'slaves of the king'. These men and women controlled state lands, political offices, taxes and the army. By the late 1700s slave men controlled taxes paid in cowrie shells, which replaced in-kind grain tribute and taxes that had been traditionally the preserve of palace concubines. Cowrie-based revenues allowed the king to build and engage in larger universe of trade. Since few grains now entered the palace as taxes, agricultural slave estates were created to fill the palace's monumental grain needs. In the early 1800s the king placed a powerful palaces slave in charge of his rural agricultural slave labour force, additionally creating the title and position of King of Grain to serve under him. The latter monitored the gathering of estate grains (in addition to grain tribute and some grain taxes) and the storage of these grains in the large palace granaries.

days after birth. Though the British colonizers outlawed palace slavery in 1926, many persons of slave descent continue to scarify their children with the $u k u$-uku out of pride, all of them, when asked, identifying themselves as bayin sarki (slaves of the king). Indeed the British outlawed the institution, and exiled the most powerful titleholders along with their households, because these men were actively thwarting British rule - not relaying messages to the emir, for example, or disobeying British directives. 
After brainstorming and some experimentation, ${ }^{4}$ we decided that I would produce and hang a very large format image of Sarkin Hatsi high up on the large square pillar on the side facing the entrance to the exhibit. It would be large and striking enough to catch the attention of all who entered, an image that would effectively greet the public. In very large font above the image would be the question, 'Who is this man?' The bottom of the poster would feature a multiple-choice answer: 'A king? A wealthy merchant? An Islamic scholar? A slave?' Underneath the image on a separate poster would be placed the 'answer' to the question: 'A slave'. Additional text below the answer would then explain that certain male and female slaves in the Kano palace had historically wielded substantial powers. At the same time, we kept the smaller photograph of the King of Grain in the regular exhibition line-up, the catalogue caption providing additional information, explaining Sarkin Hatsi's position in the palace (as keeper of the granaries) and describing the kinds of power he and others wielded in the past.

My discussions with Dr Davenport led me additionally to think through ways of framing Sarkin Hatsi's position in a larger global context. I therefore decided to create a very large triptych, comprising three columns of text, on one of the exhibition walls that would provide comparative historical geographical information. To accomplish this, I solicited the assistance of other slavery scholars whose authority on their respective topics would be made clear. The left column was titled 'Slavery in the ancient Roman Empire: 2000 BCE to 230 CE', and was written by J. Albert Harrill, an expert in the field. ${ }^{5}$ At the top of the column was a large coloured map of ancient Rome, showing the extent of the empire during its central period. The text explained how ancient slavery was not based on race or skin colour, how Greeks and Romans acquired slaves from all over the Mediterranean, and how some slaves served in professional fields, like medicine and education, while others were trained as poets, business managers, and philosophers. It also made it clear that "most slaves lived and died under a brutal system that never questioned the morality of enslaving fellow humans and had no abolitionist movement'. The central column, 'Islamic slavery in the Mamluk sultanate of Egypt and Syria: 1250 to 1517 CE', shifted the focus of attention toward Egypt and several centuries into the future, a second map above the text similarly showing the location of Mamluk rule. Written by Warren Schultz, Associate Editor of Mamluk studies review, the text explained how Islamic law allowed for many different types of slavery and the importance of slave warriors, describing the Mamluk context, where 'young non-Muslim boys [were] purchased from outside the Islamic world'; these boys trained as soldiers, eventually gaining so much power that they overturned the rule of an Egyptian ruler and assumed power themselves.

The Mamluk scenario provided an ideal segue into the Kano context, given that one Kano scholar recently referred to Kano palace slaves of the past as 'Kano Mamluks'. ${ }^{6}$ The third column, "Elite or "high status" slavery in the Kano palace, northern Nigeria: circa 1500 to 1926 CE', similarly capped by an appropriate map, emphasized how formidable Kano was, and how '[w]ithin the palace, concubinage and eunuchism, common to sultanates of the period, were instituted'. I also described in detail the importance of concubines, and explained how Islam guaranteed them certain juridical rights. 
The triptych therefore educated the wider public about an entirely different geography of slavery tied to ancient empire-building and war, rather than modern racism and economic profit. While I certainly did not want to glorify any kind of slavery, the triptych helped make clear some important differences.

\section{Representing futures}

Although the Emir, His Highness Alhaji Ado Bayero, had given me permission to have the DuSable exhibition, it was hoped that he would have direct input into the choice of photographs. A trip to Nigeria was planned in July 2003, in part for this purpose. Unfortunately, two weeks before my departure I learned that I had to have emergency spinal surgery. I was therefore compelled to rely on a sense of cultural propriety and phone calls, the latter used to confer regularly with Sadiya's husband (Sanusi Lamido Sanusi), who is also the grandson of a former emir. Though the Emir could not attend the exhibition opening on 13 September, he planned to come a few days later, following a business-related trip to the east coast. Hurricane Isabel, however, forced him to abandon that plan and he left immediately for London. Nonetheless, two representatives from the Nigerian Consulate in Atlanta attended the opening of the exhibition, including a friend of the royal family. Sanusi Lamido Sanusi also visited the DuSable curator and the exhibit several days before the exhibition ended. In order to communicate the museum event to the royal family at large, I brought catalogues to all of the wives (4) and concubines (12) when I was finally able to visit Kano in mid-November. The very large museum banner advertising the exhibition was at this time given to the second wife of the emir as a gift, since it featured two of her very young children dressed in finery, staring out at those below them with a regal gaze. Many palace persons later requested additional copies and/or asked that they or their kin be included (or not included) in the next catalogue. ${ }^{7}$ About 30 catalogues were given to one of the emir's wives, who began selling them to 'white people' who came to visit her in her palace quarters (she is the main patroness for outside women). There was also plenty of time to confer with the emir about the content and structure of the forthcoming photographic history book. After consulting with his daughter Sadiya on protocol, I requested of the Emir that she should be allowed to work with me on the book as a co-author, a similar request being made to Sanusi Lamido Sanusi, both men agreeing.

The representational dilemmas described here are part of any intersubjective project, intersubjectivity always being a very partial and highly political and mediated process. The photographic history book that Sadiya and I hope to produce in the near future, also named Disrupting perceptions, will take the intersubjectivity process a bit further. Opposite large-format photographs of particular objects and places and persons will be two captions, one in English and the other in Hausa. My caption will use its space to reflect on the object at hand in order to disrupt the perceptions of English-speaking people; Sadiya's will be crafted in Hansa not as a translation, but as entirely separate text that addresses the misperceptions of Nigerians and even those living in Kano, persons who imagine all sorts of fantastical things happening behind the high, impenetrable walls 
of the palace. In this way, the same photograph becomes a node for channelling very different sorts of contextualized knowledges and hence representational and historical processes, these knowledges lying side by side, their partial incommensurability a leisured, pleasurable fact rather than a place of anxiety.

\section{Acknowledgements}

Thanks to Nitza Rosario for her comments on this text and to Catherine Nash for her encouragement.

\section{Notes}

1 Concubines and power: five bundred years in a northern Nigerian palace (Minneapolis, University of Minnesota Press, 2004).

2 The official website of the DuSable museum relays the history of the museum, the oldest of its kind in the country, which began in 1961 when Margaret and Charles Burroughs, along with other Chicago artists and educators, recognized the institutionalized omission of black history and culture in the education establishment and set out to found a museum to rectify the situation. The first site was located in the Burroughs' home, the home itself having a long history of serving the African American community (bttp://www.dusablemuseum. org/about_dusable_museum_history.html). In 1968 the site was renamed after Jean Baptiste Pointe DuSable, the Haitian fur trader who was the first permanent settler in Chicago. As the website states: 'In 1971, the Chicago Park District granted the museum's request to use a former park administration building in Washington Park. The museum became the city's principal memorial to Jean Baptiste Pointe DuSable and the eighth member of the consortium of museums on Park District land. In 1993, the museum opened a new wing bearing the name of the late Mayor Harold Washington that included additional gallery space. The DuSable Museum remains a community institution dedicated to serving the cultural and educational needs of our members. Our research, curatorial and educational divisions are committed to listening and responding to these needs, as well as the ever-increasing demands of art and cultural historians nationwide.'

3 He assured me that she would think nothing of it. When I revisited the palace in 2003, Sadiya was surprised to see herself in the catalogue; her husband had apparently never asked her permission. I was at first quite taken aback, but she seemed to take pride in the fact, handing out many of the catalogues I brought with me to friends and family members and agreeing to work with me to co-author a photographic history book on the Kano palace.

4 We initially thought of creating a life-size cut-out of his image, but because enlarging the transparency-based image to such a large size would have produced an image far too grainy to be of much use, we decided against it. Besides, keeping viewers away from the cut-out (who might inadvertently knock it over) would be logistically impossible. Practical considerations hence led to a less interactive representational format.

5 J. Albert Harrill, The manumission of slaves in early Christianity (Tübingen, J.C.B. Mohr Paul Siebeck, 1995).

6 Sean Stilwell, 'The power of knowledge and the knowledge of power: kinship, community, and royal slavery in pre-colonial Kano, 1807-1903.', In Slave elites in the Middle East and Africa, ed. Miura Toru and John Edward Philips (London, Kegan Paul International, 2002), pp. 117-56. 
7 Those most adamant about not being included were the royal wives and the most senior concubines, who consider photographs a voyeuristic tool that would expose them unnecessarily to the public. I have never shown photographs of any of these women, except for Asmau, whose face is obscured and who cannot be identified. Her approval of the image when I later pointed it out to her upon giving her a catalogue was nonetheless clear, perhaps because it featured her as a young woman, years earlier in her tenure. 